Дужникова Екатерина Валерьевна, докторант Карагандинский государственный технический университет г. Караганда, Республика Казахстан E-mail: dizarika1@ mail.ru ORCID ID 0000-0003-0630-6273

\title{
МИНЕРАЛОГИЧЕСКАЯ ЗОНАЛЬНОСТЬ МЕСТОРОЖДЕНИЯ КОКТАСЖАЛ
}

Duzhnikova Yekaterina, doctoral student Karaganda State Technical University Karaganda, the Republic of Kazakhstan

E-mail: dizarika1@mail.ru ORCID ID 0000-0003-0630-6273

\section{MINERALOGICAL ZONALITY OF THE KOKTASZHAL DEPOSIT}

Abstract. The article considers the mineralogical zonality of the Koktaszhal deposit. The oxidation zone and the zone of primary sulfide ores are clearly distinguished. The zone of secondary sulfide enrichment is developed poorly and not everywhere. There is practically no leaching zone.

Keywords: Koktaszhal deposit, oxide ores, sulfide ores, mineralogical zonality.

Аннотация: В статье рассмотрена минералогическая зональность месторождения Коктасжал. Отчетливо выделяется зона окисления и зона первичных сульфидных руд. Зона вторичного сульфидного обогащения развита плохо и не повсеместно. Практически отсутствует зона выщелачивания.

Ключевые слова: месторождение Коктасжал, оксидные руды, сульфидные руды, минералогическая зональность.

Месторождение Коктасжал относится к меднопорфировому геолого-промышленному типу, гидротермальному генетическому типу, рудные тела представлены штокверками удлиненной изометричной формы. Руда относится к одному промышленному типу медному и к двум промышленным сортам: оксидному и сульфидному. Основное полезное ископаемое медь, попутные компоненты: золото и серебро.

На месторождении Коктасжал отчётливо выделяется зона окисления и зона первичных сульфидных руд. Плохо и не повсеместно развита зона вторичного сульфидного обогащения. Зона выщелачивания практически отсутствует.

Зона окисления хорошо выражена на всей площади распространения медной минерализации. По данным рациональных анализов её мощность (глубина распространения) колеблется от 20 до 50 м и в среднем по месторождению составляет 37 м. По отдельным узким трещинам окисленные минералы распространяются на глубину до 60 м. [1]

В пределах минерализованной зоны, окисленные медные минералы распределены крайне неравномерно и концентрируются главным образом в наиболее раздробленных и окварцованных участках, в удалении от которых интенсивность минерализации резко уменьшается. На месторождении устанавливается прямая зависимость в распределении окисленных и сульфидных медных руд. Участки и зоны с повышенной концентрацией карбонатов меди на глубине содержат повышенную вкрапленность и сульфидов меди.

Геологоминералогические науки
Материалы Международной практической интернет-конференции «Актуальные Проблемы Науки» 
Зона окисления представлена в основном малахитом и азуритом. Менее развиты хризоколла, кирпичная медная руда, самородная медь, гётит. В редких случаях, особенно в нижних горизонтах зоны окисления, присутствует халькопирит, борнит, ковеллин и халькозин. В отдельных кварцевых жилках, мощностью до 0,5 м, халькозин и борнит встречаются непосредственно на поверхности месторождения.

В зоне окисления замещение сульфидов меди окисленными минералами происходит в последовательности типичной для всех медносульфидных месторождений. По реликту гипогенного сульфида (борниту или халькопириту) с реакционной каймой ковеллина или халькозина, образовавшейся в зоне вторичного сульфидного обогащения, развивается кайма кирпичной медной руды (тонкодисперсная смесь куприта и лимонита), за ней следует кайма ноздреватого облика, состоящая из смеси кирпичной медной руды и малахита.

Самая периферическая оболочка реликта сульфида состоит из чистого малахита. Иногда между последней каймой и малахитом выделяются вкрапленники мелких кристаллов самородной меди (рисунок 1 и 2). В некоторых случаях зерно сульфида полностью замещается малахитом, но бывшая с гипогенным сульфидом ковеллиновая кайма всегда сохраняется. На рисунке 2 изображены в центре малахит (зеленый), разъединяющий кварц. Чередование кайм вверх от малахита к зерну халькопирита: кирпичная руда - ковеллин халькопирит. На границе малахита с кирпичной рудой - точки самородной меди (красная).

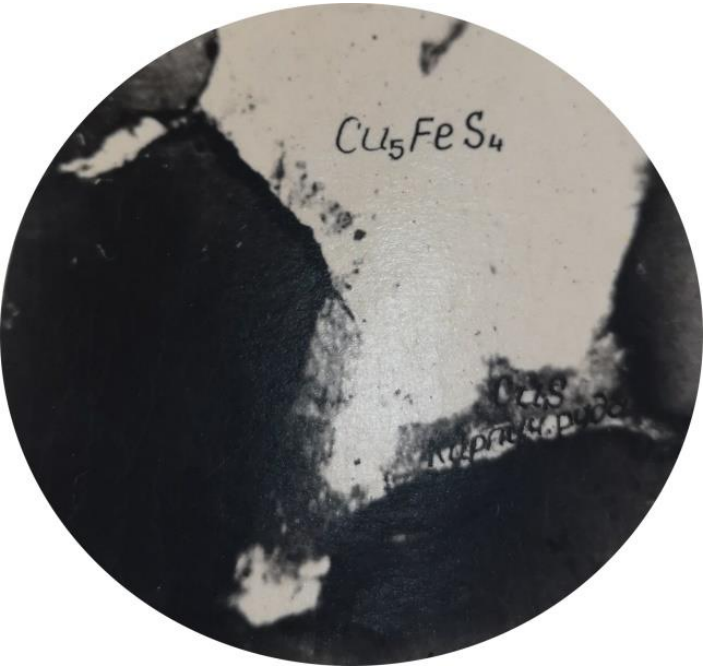

Рисунок 1 Борнит в кварие. С периферии по борниту развита кайма ковеллина, по которой в свою очередь начинает развиваться кайма кирпичной медной руды

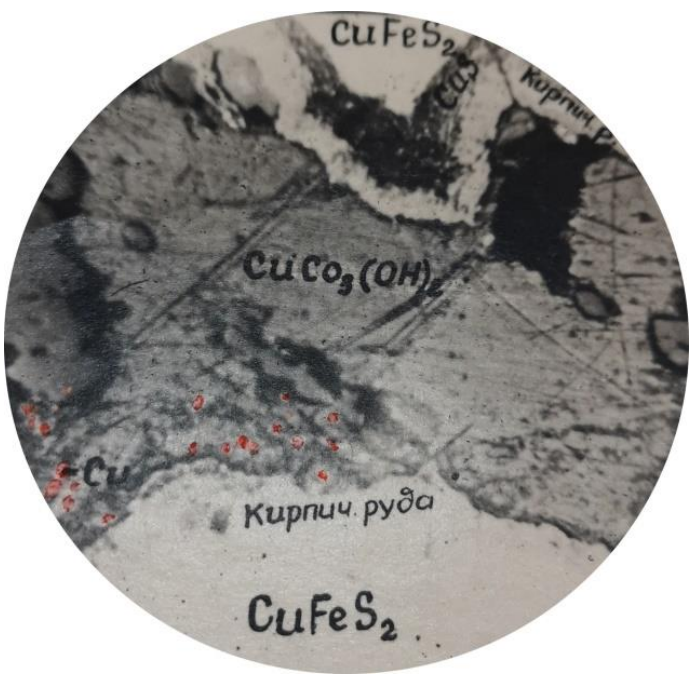

Рисунок 2 Зональные узоры вокруг зерен халькопирита.

Зона вторичного сульфидного обогащения на месторождении Коктасжал практически отсутствует. Халькозин и ковеллин представлены лишь отдельными спорадически встречающимися зёрнами. Окисленные руды обычно непосредственно сменяются гипогенными сульфидами. Процессы вторичного сульфидного обогащения более или менее отчётливо проявлялись лишь на участке между разведочными профилями XIII - XVI, где они некоторыми скважинами подсекаются на глубинах от 22 до 60 - 92 метров. Отдельные узкие

Геологоминералогические науки
Материалы Международной практической интернет-конференции «Актуальные Проблемы Науки» 
зоны с вторичными сульфидами меди подсекаются на глубине до 124 метров. Однако и здесь наряду с вторичными сульфидами меди вещественное значение имеет и халькопирит. Кроме того, подавляющая масса развитого здесь борнита также гипогенного происхождения. С учётом последнего в зоне вторичного сульфидного обогащения гипогенные сульфиды меди присутствуют в таком же количественном соотношении, как и вторичные сульфиды. Поэтому и на этом участке месторождения зона вторичного сульфидного обогащения практически представляет собой зону смешанных сульфидных руд. Представлена она халькозином, ковеллином, халькопиритом и борнитом. Вторичные сульфиды меди (халькозин, ковеллин, частично борнит) самостоятельных выделений не образуют, а развиваясь по гипогенным сульфидам, образуют вокруг них узкие плёнки и каёмки. Наибольшим развитием пользуется халькозин, затем ковеллин и борнит. Развиваются они в виде узких реакционных каёмок вокруг гипогенных сульфидов меди (халькопирита и борнита). Халькозин и ковеллин образуют петельчатую структуру по границам зёрен первичных минералов, редко по спайности последних, причём каймы по гипогенному борниту шире чем по халькопириту (рисунок 3 и 4). Иногда зёрна халькопирита совершенно чисты, в то время, когда находящиеся рядом зёрна борнита имеют реакционную кайму халькозина или ковеллина (рисунок 4).

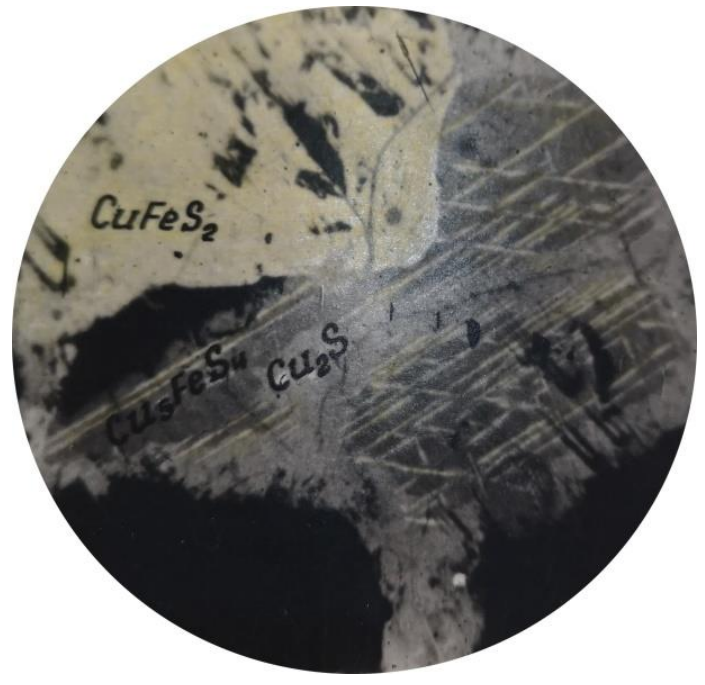

Рисунок 3 Решетчатая структура распада борнита и халькопирита. Желтыйхалькопирит. По границам и трещинам в борните (темно-серый) развивается халькозин (серый)

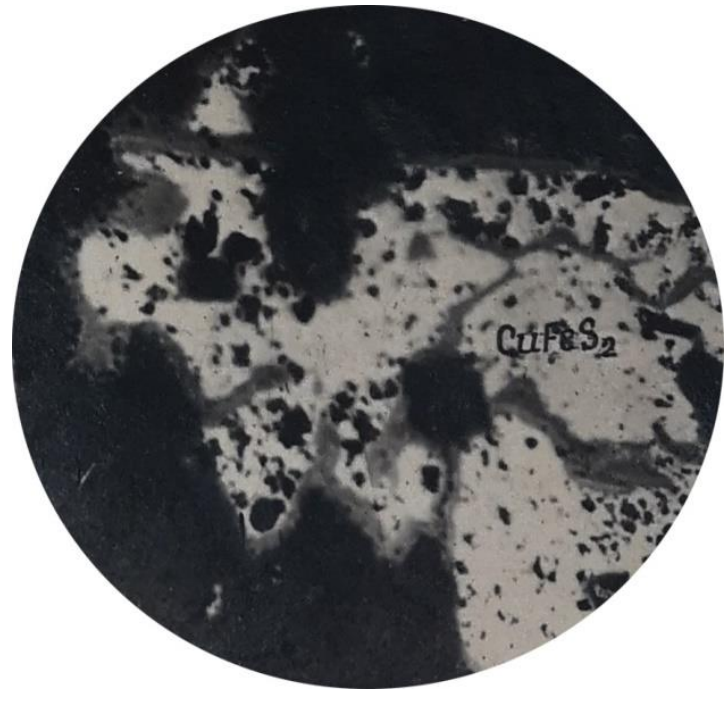

Рисунок 4 Петельчатая структура замещения халькопирита (светльй) ковеллином (серый).

Внутри ковеллиновых полосок по центру тонкие полоски медной кирпичной медной руды

Часто процесс развития халькозина идёт до образования каймы шириной до одного мм, а с периферии халькозина в свою очередь начинает развиваться кайма ковеллина. Границы между этими каймами зазубренные. В редких случаях мелкие зёрна первичных сульфидов полностью замещаются халькозином и ковеллином. Для халькозина характерным является синий цвет, свидетельствующий о значительном содержании в нём ковеллина. [2]

Зона первичных сульфидных руд на участке между разведочными профилями XIII XIV начинается с глубины 92 м и прослежена до глубины 550 м. На остальной части месторождения она начинается непосредственно за окисленными медными рудами. Буровыми скважинами гипогенные сульфидные руды изучены в среднем до глубины 460 м.

Геологоминералогические науки
Материалы Международной практической интернет-конференции «Актуальные Проблемы Науки» 
Отдельные скважины по ним пройдены на глубины до 510 м. Основными минералами первичных сульфидных руд является халькопирит и борнит, причём последний распространён крайне неравномерно. Борнит наиболее широко развит на участке между разведочными профлями XII - XVI, где до глубины 500 м отдельные зоны, в которых он является основным рудным минералом. На остальной части месторождения борнит менее распространён.

Из других минералов в первичных рудах присутствует пирит, молибденит, гематит, блеклая руда, магнетит, ильменит. [3]

\section{ЛИТЕРАТУРА}

1. Бекбулатов В.С., Шакенова К.Т. Проект разведки меди (поисковые работы) на месторождении Коктасжал в Карагандинской области на 2011 - 2017 гг., Алматы, 2010. $162 \mathrm{c}$.

2. Бекбулатов В. С., Шакенова К. Т., Утегенева М. У. и другие. Предварительная геологоэкономическая оценка меднопорфирового месторождения Коктасжал в Карагандинской области с подсчетом запасов по состоянию на 01.01.2011 г., Караганда, 2011. - 190 с.

3. Дужникова Е.В., Кряжева Т.В., Кенжин Б.М. Минеральный состав руд и условия их образования на месторождении Коктасжал // Вестник ВКГТУ, 2018.

Геологоминералогические науки
Материалы Международной практической интернет-конференции «Актуальные Проблемы Науки» 